\title{
A Review of Library Knowledge Management Research in China
}

\author{
Niu Li \\ School of Information Resource Management \\ Renmin University of China \\ Beijing, China \\ rucniuli@gmail.com \\ Han Xiaoting \\ School of Economics and Management \\ Beihang University \\ Beijing, China
}

\author{
Wang Yunhui \\ School of Information Resource Management \\ Renmin University of China \\ Beijing, China \\ Jiao Tianxue \\ School of Information Resource Management \\ Renmin University of China \\ Beijing, China
}

\begin{abstract}
Knowledge management is the process of capturing, developing, sharing, and effectively using organizational knowledge. As a business concept, it has been traditionally applied to revenue-producing organizations with the aim of increasing profits and gaining competitive advantages. However, in fact, it can also be applied to non-profit organizations such as libraries. In the knowledge economy era, the traditional management mode of library can no longer satisfy readers' need and management requirement. A review of related literature in recent years is carried out for demonstrating the need to apply knowledge management to library management, including connotations, targets, contents, patterns and technologies. The article considers that the study of library knowledge management in China have achieved certain results, but still at their early stages. It points out the shortages of the research and presents relevant expectations to show the way in the future of library knowledge management in China.
\end{abstract}

Keywords-Library management; Knowledge management; Library knowledge management; Review

\section{INTRODUCTION}

In the knowledge economy era, people's demand for knowledge has a remarkable increase. The traditional management mode of library can no longer satisfy the development of modern times. The new concept of knowledge management should be introduced to improve the overall level of library management.

The library knowledge management has become a hot area of research since the new concept of knowledge management was introduced in China, which also achieved some certain results.

Supported by the Fundamental Research Funds for the Central Universities, and the Research Funds of Renmin University of China(Project Number: 14XNJ026;Project Name: Information Diffusion and Node Influence Analysis in Heterogeneous Social Networks).

\section{THE CONNOTATION OF LIBRARY KNOWLEDGE MANAGEMENT}

\section{A. Knowledge management becomes the main trend of library management}

The role which library played is to inspire wisdom and integrate knowledge. Lin Aiyun ${ }^{[1]}$ says that traditional library management is mainly marked by documentary organization which focusing on providing explicit knowledge service for users. With the development of knowledge economy, the traditional library management has been far from meeting the requirements of times. Zhang Ye and Zhou Lei ${ }^{[2]}$ notes that the main objective of library is to serve as an institution of information resource management, including information acquisition, processing and utilization.

It's high time for library to constantly innovate in order to fulfill the requirement of library management. $\mathrm{Xu}$ Zhener $^{[3]}$ puts forward that, the function of library must necessarily be improved to keep pace with the changing needs of its readers and a mode based on knowledge management has become an inevitable way to enhance the function of library.

\section{B. The connotation of library knowledge management \\ 1) Library knowledge management based on internal management}

The library knowledge management based on internal management consists of two parts: work content of library and knowledge management of organization. $\mathrm{Du} \mathrm{Li}{ }^{[4]}$ states that the system of knowledge management should be established, which is characterized by a concept of knowledge sharing that can improve staff's capabilities and the level of management. Bai Qingmin ${ }^{[5]}$ argues that the essence of library knowledge management is the 
comprehensive management by a method of knowledge management.

\section{2) Library knowledge management based on object}

Library knowledge management based on object is a process of capturing, organizing and making knowledge resource work. Chai Xiaoping ${ }^{[6]}$ describes library knowledge management as a process of acquisition, organization, application and utilization, focus on not only explicit knowledge but also tacit knowledge. Chen Hongmei $^{[7]}$ further notes that the importance of knowledge innovation depends on the organization and development of intellectual capital. Liu Bin $^{[8]}$ and Liu Chen ${ }^{[9]}$ claim that library knowledge management is the acquisition and organization of explicit knowledge as well as the development and management of tacit knowledge.

\section{3) Library knowledge management based on management function}

Library knowledge management based on management function refers to the work of knowledge innovation and the way of supporting knowledge innovation. Luo Min ${ }^{[10]}$ believes that library knowledge management is a process of achieving knowledge value-added and knowledge sharing by knowledge chain management. Zhou Fang ${ }^{[11]}$ addresses the aim of library knowledge management is to set up a system of knowledge resource, which bases on well-established links, such as knowledge acquisition, dissemination and creation. Huang Haiying ${ }^{[12]}$ argues that library knowledge management is a combination of knowledge, information and human, with the aim of achieve implementation of knowledge sharing and transferring.

\section{THE NECESSITY OF LIBRARY KNOWLEDGE MANAGEMENT}

\section{A. The development of knowledge economy imposes new challenges on library}

Since the volume of digital information expands constantly, it becomes more and more difficult for library to exist and develop relying on traditional service mode. Wang Haiyan $^{[13]}$ argues that the changing needs of users put forward a giant challenge to traditional service, as it requires individual and in real-time service. Zhao Huiqing ${ }^{[14]}$ says that the rapid acceleration of informatization has resulted in a vast increase in challenges for libraries. The service mode and management mechanism of libraries must be necessarily changed to meet new requirements of time.

\section{B. The advantages of knowledge management theory}

Knowledge management theory has been successfully applied to enterprise, which provides a new management method for libraries. Zhao Huiqing ${ }^{[14]}$ argues libraries must alter the traditional idea and develop user-oriented service based on knowledge management theory. , Wang Haiyan ${ }^{[13]}$ claims that library can gain better management efficiency by carrying out the knowledge management program.

\section{The development of knowledge economy creates opportunities for library}

Sustained growth of information caused by knowledge economy expanding makes it urgent for library to improve management method and meet the users' need for knowledge. Liu Chuanhe and Chen Jie ${ }^{[15]}$ indicate that only combined with knowledge management theory can we promote the innovation of library science. Liang Keke ${ }^{[16]}$ also indicates that only introduce knowledge management into the library can realize its value in innovation system.

\section{THE GOALS OF LIBRARY KNOWLEDGE MANAGEMENT}

Li Jiaqing ${ }^{[17]}$ classifies goals of library knowledge management into two parts, that is ultimate goal and specific goal. Liu Shuling[18] puts that the ultimate goal of library knowledge management is to promote the core competitiveness of library. Bai Qingmin ${ }^{[5]}$ and $\mathrm{He} \mathrm{Xia}^{[19]}$ argue that the ultimate goal of library knowledge management is to achieve knowledge innovation and raise knowledge service level. "User-centered design, enhance users satisfaction" is Zhou Wenrong's ${ }^{[20]}$ understanding of this issue. To conclude, acquiring and utilizing knowledge at the maximum level to meet users' need efficiently is the ultimate goal of library knowledge management.

Zhang Bing $^{[21]}$ and Sheng Jianfeng ${ }^{[22]}$ discuss the specific goal of library knowledge management from two aspects: knowledge value-added and knowledge innovation. From the perspective of knowledge value-added, library knowledge management regards document resource as knowledge and tries to realize knowledge value-added by knowledge sharing. From the perspective of knowledge innovation, library knowledge management refers to organize knowledge and makes it well ordered. From the perspective of human, library knowledge management seeks to enrich users' knowledge and enhance librarian's qualities.

Bai Qingmin et al.establish a goal system of library knowledge management from both business process and management level (see Table1) and state that "The goal of library knowledge management is to arrange library works around goals of organization,make full use of knowledge and promote knowledge innovation." 
TABLE I. THE SPECIFIC GOALS OF LIBRARY KNOWLEDGE MANAGEMENT

\begin{tabular}{|c|c|c|c|c|}
\hline $\begin{array}{c}\text { Management } \\
\text { level } \\
\begin{array}{c}\text { Business } \\
\text { process }\end{array}\end{array}$ & $\begin{array}{c}\text { The goals of } \\
\text { librarian } \\
\text { team } \\
\text { building }\end{array}$ & $\begin{array}{c}\text { The goals of } \\
\text { IR } \\
\text { construction }\end{array}$ & $\begin{array}{c}\text { The goals } \\
\text { of user } \\
\text { service }\end{array}$ & $\begin{array}{c}\text { The goals of } \\
\text { infrastructure } \\
\text { construction }\end{array}$ \\
\hline $\begin{array}{c}\text { Individual } \\
\text { innovation } \\
\text { goal }\end{array}$ & $\begin{array}{c}\text { Individual } \\
\text { innovation } \\
\text { of librarian } \\
\text { team } \\
\text { building }\end{array}$ & $\begin{array}{c}\text { Individual } \\
\text { innovation of } \\
\text { IR } \\
\text { construction }\end{array}$ & $\begin{array}{c}\text { Individual } \\
\text { innovation } \\
\text { of user } \\
\text { service }\end{array}$ & $\begin{array}{c}\text { Individual } \\
\text { innovation of } \\
\text { infrastructure } \\
\text { construction }\end{array}$ \\
\hline $\begin{array}{c}\text { Team } \\
\text { innovation } \\
\text { goal }\end{array}$ & $\begin{array}{c}\text { innovation } \\
\text { of librarian } \\
\text { team } \\
\text { building }\end{array}$ & $\begin{array}{c}\text { Team } \\
\text { innovation of } \\
\text { IR }\end{array}$ & $\begin{array}{c}\text { Individual } \\
\text { innovation } \\
\text { of user } \\
\text { service }\end{array}$ & $\begin{array}{c}\text { Individual } \\
\text { innovation of } \\
\text { infrastructure } \\
\text { construction }\end{array}$ \\
\hline $\begin{array}{c}\text { Organization } \\
\text { innovation } \\
\text { goal }\end{array}$ & $\begin{array}{c}\text { Organizatio } \\
\mathrm{n} \text { innovation } \\
\text { of librarian } \\
\text { team } \\
\text { building }\end{array}$ & $\begin{array}{c}\text { Organization } \\
\text { innovation of } \\
\text { IR }\end{array}$ & $\begin{array}{c}\text { Individual } \\
\text { innovation } \\
\text { construction }\end{array}$ & $\begin{array}{c}\text { Individual } \\
\text { innovation of } \\
\text { infrastructure } \\
\text { service }\end{array}$ \\
construction
\end{tabular}

\section{THE CONTENT OF LIBRARY KNOWLEDGE MANAGEMENT}

No agreement is reached, though a great deal of research related to library knowledge management has been conducted. On the basis of analysis of different arguments, there are several representative views.

\section{A. Library knowledge management based on knowledge management process}

Library knowledge management based on management process contains knowledge acquisition, organization, innovation and other links. Xia Ping ${ }^{[23]}$ describes it from five respects: (1) Knowledge production management. It means digitalization and store knowledge into computer and make the information transferring through Internet. (2) Knowledge organization management. (3)Human resource management. Human resource management attaches great importance to the cultivation of quality librarians and supports creativity.(4)Knowledge innovation management. Knowledge innovation management consists knowledge theory, knowledge technology and knowledge organization. (5) Knowledge application and dissemination. Knowledge application and dissemination is to digitize library resource and offer a user-centered method of information distribution and retrieval.

\section{B. Library knowledge management based on knowledge resource}

Library knowledge management based on knowledge resource depends on its own knowledge management, which is the core of library knowledge management. Mao $\mathrm{Yi}^{[24]}$ and $\mathrm{Li}$ Haiying ${ }^{[25]}$ conclude the content of knowledge management from two aspects.

First, library's social function. It embodies in the organization and transmission of explicit knowledge.

Second, taking library as a social organization. It embodies in the capacity-build of librarian and the promotion of tacit knowledge sharing.

\section{Comprehensive library knowledge management}

Yang Guirong ${ }^{[26]}$ summarize its content as "one goal, one foundation, three levels, four processes and five links." It consists of knowledge innovation, knowledge capital management and knowledge link management, in order to achieve the goal of library knowledge management through mutual coordination.

\section{LIBRARY KNOWLEDGE MANAGEMENT MODE}

\section{A. "Three-level" knowledge management mode}

"Three-level knowledge management mode" is carried out by Sheng Xiaoping and Xu Yinchi ${ }^{[27]}$, dividing library knowledge management into three levels: establish knowledge management system, cultivate knowledge workers and enhance knowledge service capacity

Shao Yunfeng ${ }^{[28]}$ points out the significance of this mode: (1) This mode embodies the core content of library knowledge management, which is important to promote capacity of library knowledge service.(2) This mode has defined the basic process of library knowledge management. (3) This mode makes it clear about the relationship among library management, which has profound guiding significance for the establishment of library knowledge management.

\section{B. Explicit knowledge management mode}

Explicit knowledge management mode based on document resource is to develop the knowledge value of document by taking document as knowledge. Feng Qin and Ge Haiyan ${ }^{[29]}$ argue that explicit knowledge management mode is to intensify the utilization of knowledge resource and promote knowledge sharing. Liu Chuanhe ${ }^{[15]}$ claims that to provide users with efficient service, it requires arranging holdings well-ordered, realizing resource digitalization and making virtual resource available.

\section{Tacit knowledge management mode}

Tacit knowledge management mode is user-centered and librarian-centered, it focusing on strengthening the training of librarians, promoting knowledge sharing and improving the ability of users to use library. Shi Suzhen and Wang Qiong ${ }^{[30]}$ claim that tacit knowledge management means establishing knowledge organization, building knowledge repository and constructing learning library. Wang Fuquan $^{[31]}$ says library tacit knowledge management is to "build tacit knowledge repository and a platform for knowledge transformation, so as to achieve knowledge management in the course of readers' practice."

\section{Knowledge service mode}

Knowledge service mode based on knowledge management is to establish relevant technical facilities, promote knowledge communication inside the library between libraries and users. Li Lingyu ${ }^{[32]}$ summarizes several factors should be included in library knowledge service system, such as knowledge service platform, knowledge repository and other factors. A knowledge 
service system which can provide users with self-determination, professional and personalized service is Sheng Jianfeng's ${ }^{[22]}$ view of this issue.

\section{LIBRARY KNOWLEDGE MANAGEMENT TECHNOLOGY}

Generally, library knowledge management technology includes computer technology, metadata description standard technology and cross-database retrieval technology. Specifically, library knowledge management technology is information technology based on computer. Well, scholars generally agree with the definition of general one. Dong Shaojie and Jiao Fangmei ${ }^{[33]}$ conclude that library knowledge management technology consists of information storage and management technology, information search and access technology. Gong Jiaoteng ${ }^{[34]}$ puts that library knowledge management technology is the digital network technology, which manages library from document unit into knowledge unit. Zhang Fuxue ${ }^{[35]}$ summarizes there are three tools to achieve library knowledge management: knowledge production, knowledge encoding and knowledge transfer.

In addition, Liu Chuanhe and Chen Jie ${ }^{[16]}$ divide library knowledge management technology into explicit knowledge management technology and tacit knowledge management technology, based on existing knowledge classification. Explicit knowledge management technology contains explicit knowledge encoding technology, metadata technology and retrieval technology, and etc. Tacit knowledge management technology includes e-mail, electronic work platform and other technology.

Library knowledge management technology is a growing technology system covers many aspects of knowledge management to help people acquire and share knowledge, as well as promote library to provide better service.

\section{RESEARCH PROBLEMS AND PROSPECTS OF LIBRARY KNOWLEDGE MANAGEMENT IN CHINA}

Since the introduction of knowledge management in the library, the study on library knowledge management in China has improved rapidly, but still a long way to go.

\section{A. Problems in research}

The research on library knowledge management in China is still purely theoretical and lack of practice. Many scholars have begun to focus their attention on the application field, but most of them hold exactly the same opinion without innovation.

The study of library knowledge management in China is still in a passive position. Mostly, the theory of library knowledge management comes from enterprise knowledge management and creative theory is needed.

In general, the study of library knowledge management in China emphasizes on theory but ignoring the practice. It fails to achieve a good combination of theory and practice.

\section{B. Prospects for future research}

Taking the existing problems into consideration, we should strengthen the research on following aspects: first, expand research field and deepen research level on the characteristics of library itself. Second, learn from the experience of foreign library. What's more, it's necessary to improve the inadequate study in this aspect such as knowledge information, tacit knowledge management and application technology, so as to accelerate the process of practice and application in library knowledge management.

\section{REFERENCES}

[1] Liu Aiyun. The management of documents and the management of knowledge in libraries[J]. Journal of The National Library of China, 2005 (2): 41-45. (In Chinese)

[2] Zhang Yan, Zhou Lei. The developing strategies of knowledge management at libraries[J]. Library and Information Service, 2003(7): 108-111. (In Chinese)

[3] Xu Zhener. On knowledge management of library[J]. Journal of Information, 2007, 26(8): 149-150. (In Chinese)

[4] Du Yeli. Analysis of the core content of library knowledge management[J]. Journal of Information, 2002 ,21(9):17-18. (In Chinese )

[5] Bai Qingmin, The design of the mode of library knowledge management[J]. Journal of Information, 2005,24(4): 30-32. ( In Chinese)

[6] Chai Xiaoping. Library knowledge management- How far we can go?[J]. Library Theory and Practice, 2007(3): 16-17. (In Chinese)

[7] Chen Hongmei. Analysis of the innovation mechanism of Library Knowledge Service[J]. Knowledge of Library and Information Science, 2004(5): 79-81. (In Chinese)

[8] Liu Bin. The study of the knowledge management of library[J]. Library, 2005(4): 88-89. (In Chinese)

[9] Liu Chen, Tu Hang. Model about library information portal of knowledge management[J]. Information Science, 2006,23(12): 1856-1860. (In Chinese)

[10] Luo Min. Research on building the library culture based on knowledge management[J]. Library and Information Service, 2007, 51(6): 55-58. (In Chinese)

[11] Zou Fang. The innovation of library knowledge management[J]. Journal of Information, 2005, 24(2): 114-115. （In Chinese )

[12] Huang Haiying. Constructing the new knowledge management system in library[J]. Library, 2005(1):77-78. (In Chinese )

[13] Wang Haiyan. On knowledge management of library and actualizing strategies[J]. Information Science, 2006, 24(9): 1325-1328.(In Chinese )

[14] Zhao Huiqing. Research on library knowledge management and innovation[J]. Information and Documentation Services, 2009(3): 95-98. (In Chinese)

[15] Liu Chuanhe, Chen Jie. The basic theories and actualization of library knowledge management[M]. Beijing: Ocean Press, 2007:72. ( In Chinese)

[16] Liang Keke. The innovation of library service based on knowledge management[J]. Information and Documentation Services, 2006(3): 89-92. (In Chinese)

[17] Li Jiaqing. the basic character and actualizing strategies of library knowledge management $[\mathrm{J}]$. Knowledge of Library and Information Science, 2003(1): 11-13. (In Chinese)

[18] Liu Shuling. On Knowledge Management and Library Core Competitiveness[J]. Information Science, 2012, 29(12): 1773-1776. （In Chinese)

[19] He Xia. The significances, difficulties and countermeasures of library knowledge management[J]. Library Theory and Practice, 2007(4): 21-22. 
[20] Zhou Wenrong. Free to use knowledge and the knowledge management in library[J]. Knowledge of Library and Information Science, 2001(3): 12-14. (In Chinese)

[21] Zhang Bing. Knowledge management in modern libraries[M]. Beijing: Intellectual property publishing house, 2008: 80-82. (In Chinese)

[22] Sheng Jianfeng. Research on the library knowledge management and service[M]. Beijing: Science Press, 2012: 64-66. (In Chinese)

[23] Xia Ping. The main content and operation tactics of knowledge management in library[J]. Information Science, 2003, 21(7): 718-720. (In Chinese)

[24] Mao Yi. The main contents of knowledge management in university libraries[J].Library and Information Service,2002(10):58-61.(In Chinese)

[25] Li Haiying. The basic theories and actualizing strategies of library knowledge 14-16. (In Chinese)

[26] Yang Guirong, Mao Ganming, Song Jinglin. On the research of library knowledge management[J]. Library Tribune, 2007, 27(1): 1-5. (In Chinese)

[27] Sheng Xiaoping, $\mathrm{Xu}$ Yinchi. On the research of the library management patterns based on knowledge management[J]. The Journal of The Library Science In China, 2006, 31(6): 18-24. (In Chinese)
[28] Shao Fengyun. On the research of the library management patterns based on knowledge management[J]. Journal of Henan Science and Technology, 2014(1):181-182. (In Chinese)

[29] Feng Qin, Ge Haiyan. Discussion on the strategy of library knowledge resource construction[J]. Journal of Intelligence, 2011, 29(B12): 185-187.(In Chinese)

[30] Shi Suzhen, Wang Qiong. On the research of the models of library tacit knowledge management[J]. Library, 2006(6): 79-81. (In Chinese)

[31] Wang Fuquan, Luo Zhongfeng, Guo Shiming. Knowledge management of library based on the reader tacit knowledge[J]. Information Science, 2010(2): 219-222. (In Chinese)

[32] Li Yuling. Modes of knowledge services in library[D]. Jilin: Jilin University. 2006. (In Chinese)

[33] Dong Shaojie, Jiao Fangmei. To strengthen the service for readers of the library based on knowledge management[J]. Researches In Library Science, 2003(2): 76-78. (In Chinese)

[34] Gong Jiaoteng. The development of library knowledge management from the perspective of literature $[\mathrm{J}]$. Researches in Library Science, 2008(3): 58-61. (In Chinese)

[35] Zhang Fuxue. The design and implementation tools of knowledge management system[J]. Journal of Information, 2002(3): 53-54. (In Chinese ) 